d'aider toutes les sections à mieux performer.

En tant que membre de l'institut, j'aimerais savoir si vous considérez que l'Institut vous en donne assez pour votre argent. Si la réponse est non, prenez le temps d'identifier ce qui manque et ne tardez pas à en informer le Bureau de direction ou votre conseil de section. Je vous encourage également à faire part d'événements ou d’activités spécifiques que vous aimeriez voir se dérouler dans votre section. Et pourquoi norganiseriez-vous pas vous-même une activité pour les membres! Vous voulez aller encore plus loin? Les conseils de section changent chaque année ou tous les deux ans, sans compter que les portes des conseils vous sont toujours ouvertes.

Notre plan d'action national est clair et précis et vise à en donner toujours plus à nos membres selon nos cinq objectifs principaux. Si vous ne l'avez pas encore fait, exprimez-vous et faitesnous savoir ce à quoi vous vous attendez en tant que membre. Je suis prête à mener la charge à vos côtés, vous, nos membres, notre base et notre force.

\title{
The Evolution of Forest Management in Canada: Management Paradigms and Forest Tenure Systems
}

\author{
by Tony Rotherham RPF (BC, ON ret) and K.A. Armson O.C. RPF (ret)
}

Forest ownership and forest land use in Canada

Canada has 400 million ha of forested land. Only 190 million ha $(47 \%)$ is considered economically productive and under active management. Some 165 million ha (41\%) is in public ownership and 25 million ha (6\%) in private ownership, a mix of 450000 private woodlots ( $20 \mathrm{~m} \mathrm{ha}$ ) and larger holdings (5 $\mathrm{m}$ ha).

In 2015 the Canadian forest industry's production was valued at $\$ 65$ billion. Exports totaled $\$ 33$ billion delivered to customers in over 100 countries around the world. The industry supported an estimated 233000 direct jobs including 9000 Aboriginals (FPAC). There are an estimated 231 forestdependent communities across Canada. It is essential to maintain excellent forest management and stewardship systems to ensure the long-term health and productivity of the forest resources, the foundation of a competitive industry able to support families living in those 231 forest-dependent communities.

The value of all forest-based recreational activities is also very significant. The Sustainable Forest Management paradigm is our present model to achieve efficient management for all forest values. The 165 million ha of actively managed forest land in public ownership, is the main focus of this article.

\section{The Evolution of Forest Management in Canada}

It is useful to consider the evolution of the use, exploitation and management of Canadian public forests over time, in order to gain a sense of how management of these forests has evolved and can be improved.

The term Forest Management Paradigm (Fig. 1) is often used to identify these evolutionary stages of management, which have been mainly the result of Reactive Evolution to social and economic change.
It might be argued that while the growth and ecosystem functions of the vast Canadian forest has remained unchanged during the 400 years since European settlers came to Canada, the demands on the forest have changed radically. And so has the level of population, public awareness, education and values. Our knowledge of the forest and the library of forest science have also increased.

Changes in the forest management paradigms were due to increases in population, growing demands on the forest for wood to meet the changing needs of society and changes in technology and societal values.

First Nations Peoples generally lived "in and with" the forest rather than "exploiting" it to meet their needs. The exception to this broad generalization was the practice of shifting agriculture used by the First Nations living in southern Ontario and Quebec.

\section{Subsistence \\ Prior to 1600 the management paradigm was essentially Sub- sistence use of the forests by an estimated 300000 to 500000 First Nations peoples. In some areas such as southern Ontario and Quebec, this included significant forest clearing for shift- ing crop production. The period 1600 to 1800 brought an influx of European settlers whose main activities were the clearing of the forest for agriculture and the establishment of water-powered mills for local lumber production.}

\section{Forest Resource Exploitation}

It was not until the early 1800 s and particularly after Napoleon's blockade of Britain's access to Baltic timber that Exploitation of pine and oak forests in Eastern Canada took place. During this period the forest was 'mined' for timber with little or no thought to regeneration, fortunately on a relatively small scale. 


\section{FOREST MANAGEMENT PARADIGMS Pre-1600 to Present}

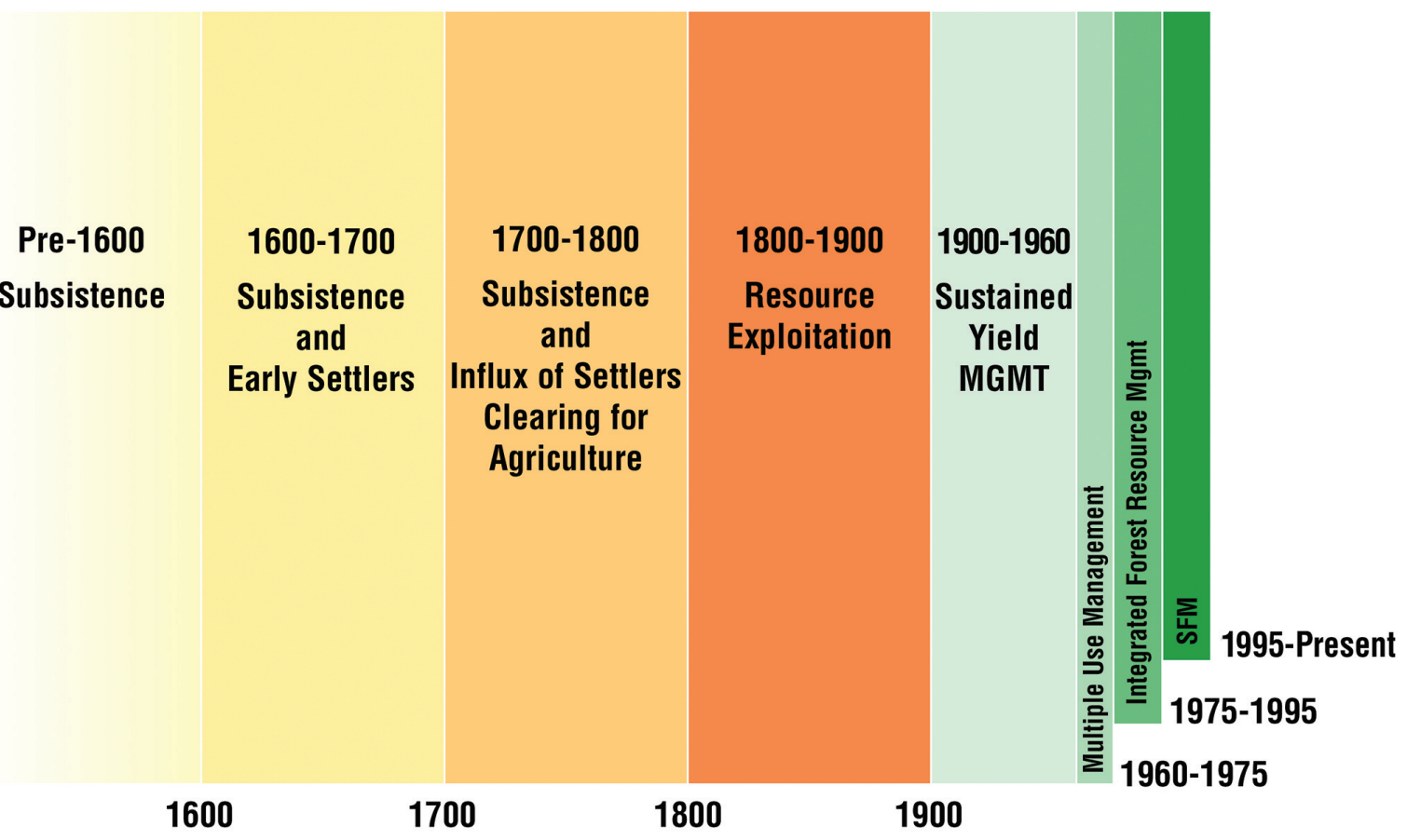

Fig. 1. Forest Management Paradigms

\section{Sustained Yield Management}

Beginning at the end of the 1800 s and into the early decades of the 1900s saw the rise of the pulp and paper industry, which required a large and secure timber supply. The industry was established first in eastern Canada and later in British Columbia. The wood supply was provided through the allocation by provinces of large areas of Crown forest with a requirement for the practice of Sustained Yield Management. This required forest inventories, growth calculations and establishment of allowable annual harvest levels and longterm planning. The focus was on wood supply.

\section{Multiple-Use Management}

1960-1975. It was during this period that the concept of Multiple-Use Management was implemented. As Canadians recovered from WW II, public pressure to use the forests for recreation, hunting and fishing grew as leisure time increased and desire for outdoor recreation flourished. The forests were more accessible due to the networks of forest roads. The needs of the public users had to be considered and changes were made to management planning and operations to accommodate public use of the forest.

\section{Integrated Forest Resource Management}

During the early 1970s there arose the need to integrate other values into the forest management planning process. These included non-timber elements such as wildlife, fisheries, recreational use, ecological values such as "old growth" and impacts on the forest landscape. This new paradigm was called Integrated Forest Resource Management.

\section{Sustainable Forest Management}

Beginning in 1995 and continuing to the present, the values and function of forest ecosystems were recognized in the concept of Sustainable Forest Management (SFM). SFM in Canada is based on a set of Criteria and Indicators (C\&I) developed through the Montréal Process, a United Nations intergovernmental discussion of the science and policy of forest management appropriate for the Non-European Temperate Forests of the world.

In Canada, SFM is defined by the well-known six Criteria and Indicators approved by the Canadian Council of Forest Ministers. It is important to respect the Economic, Environmental and Social values that support the "3-Legged Stool" of Sustainability.

\section{Forest Tenure Agreements}

Forest tenure agreements have two central purposes:

- To establish the conditions under which timber is made available to the marketplace, and

- To allocate responsibility and accountability for the performance of forest management requirements specified in regulations and policy. 
Typically, tenure agreements have been signed between a Province, as owner of the forest land, and a forest products company that owns and operates timber processing facilities. The agreements provide the tenure-holder with rights to harvest timber from publicly owned forest land together with a set of specified responsibilities for forest management. Tenure agreements have rarely been signed between the Province and an independent forest manager.

Historically, many of the large forest products companies have been able to look back on 50 years of management of a specific area of forest. Unfortunately there has been no ability to look ahead with confidence into the future for the next 50 years of access to the wood supply. This has reduced the incentive for industry to invest in silvicultural treatments to improve forest productivity and the quality and value of the timber.

Forest tenure agreements are almost always framed in provincial forest management legislation. This results in periodic change at intervals of about two decades to keep in step with perceived changes in public values and perhaps more specifically, to conform to the political and economic philosophy of the government of the day. These periodic changes in tenure often result in uncertainty about the future allocation of timber supplies and the division of responsibility for woodlands management and operations.

This raises a question about the ability of the existing tenure systems to provide for the long-term management and productivity of public forests. We must recognize that there will be changes in both timber and non-timber values and uses and the markets for both-often related to changes in technology. Flexibility is required.

A further consideration is that forest-based communities, including First Nations, throughout Canada have had little active participation in forest management decision-making, although they are often economically dependent on forest management operations and timber processing. Public participation in the development of long-term forest management plans is important but must recognize the essential responsibilities that reside with the forest managers.

Despite these realities we must develop and implement a form of tenure that will ensure good forest management and provide incentives to improve forest health, productivity and to support a competitive industry. It is of fundamental importance, to both communities and industry, to have a forest that is healthy, productive and with high quality trees, that creates an essential alignment of objectives between the two parties. Communities bring the social aspect to the table. Industry brings knowledge of the marketplace and tree quality required to support a competitive industry.

Why is tree quality important? From the early 1900s to about 1985 the majority of roundwood harvested in eastern Canada was delivered to the pulp and paper industry. The $\mathrm{P} \& \mathrm{P}$ industry is almost agnostic about log size and form. Big or small they go into the chipper. The P\&P industry now relies on sawmill chips for their fibre supply. Since 1985 a growing majority of logs have been delivered to sawmills. Tree quality (log size and quality) are of critical importance to a competitive lumber industry.

Provincial governments have comprehensive regulations to ensure the maintenance of environmental values, public access and recreation. Forest tenure agreements can be long- term (20-25 years) and renewable, or short-term ( $1-5$ years), depending on the circumstances. Only secure long-term timber supply agreements provide any reasonable basis for forest management planning and industrial investment. Stumpage payments to pay for and transfer ownership of the harvested wood from the province to a privately-owned industry are generally separate from the tenure agreement.

As illustrated in the section on the evolution of forest management paradigms, it is essential to recognize and accommodate changes in public values and expectations. This is particularly true in a country like Canada with a well-educated population and good communications. Forest tenure agreements are developed and implemented within the socio-political conditions of the day. They must reflect economic, social and environmental realities. A few to consider are:

- The management of forest resources in northern regions of Canada, far from urban centres, may not be a "top-ofthe-mind" concern of governments with many calls upon the attention of legislatures and the public purse-public health, education and transportation infrastructure, to name but a few.

- The prosperity of rural and northern forest-dependent communities depends on the health, productivity and economic potential of the forests that surround them. They have a real "stake" in forest management.

- The need to include First Nations in resource management and economic benefits.

- Forest products companies must invest in modernization to remain competitive.

- There are currents in today's society that seem to ignore the economic and social well-being of large segments of society. "Social License" is deemed an essential pre-requisite for any activity or project outside an urban area. Perhaps a better term would be community support.

- Most contracts in society are short-term, perhaps at most 20-25 years. Politicians manage on a much shorter cycle4 to 5 years. The planning, investment and return horizons in forestry are much longer-extending 50 to 80 years for both forest resource management and capital-intensive mills.

- A case can be made that responsibility for many aspects of forest management and field operations can be most efficiently handled by the private sector. Governments can hold the private sector accountable for performance. There have been occasions in the past where governments have not fulfilled their responsibilities in a timely fashion (the immense accumulation of NSR in the 1970s).

If a tenure agreement is well-designed it can help to accommodate the concerns and conditions noted above.

A truly successful forest tenure model will include:

- A contract that will be respected for the length of the agreement and that is long enough to:

- Enable and promote long-term forest management planning, infrastructure development and silviculture treatments to improve forest health, productivity and tree quality.

- Justify and support investment in industrial development, modernization, training and productivity to maintain a competitive industry.

- The contract will be renewable if all performance requirements are met. 


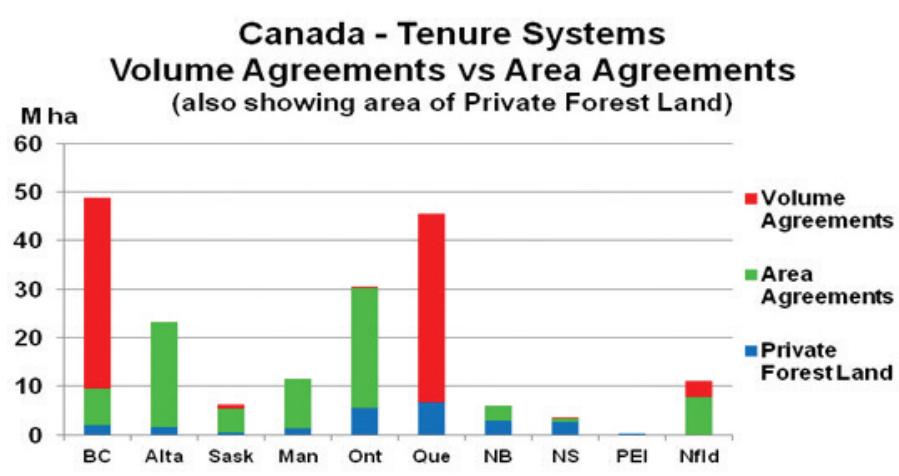

Fig. 2. A survey of tenure systems in all provinces (Neave and Rotherham २0०2; unpublished]. Note: The pattern is due to a mix of history and political preference.

- Incentives to promote silvicultural treatments to improve forest health, productivity and tree quality.

- Provisions that meet the needs and objectives of government.

- Involvement of resource dependent communities, including First Nations. They are as affected by, and dependent on, the forest resource as are the forest products companies.

There must be clear allocation of responsibilities and accountability for various aspects of forest management among the parties to the agreement. Care must be taken that responsibility for planning and execution of operations such as harvest, regeneration and stand maintenance are integrated.

- Forest management performance shall be audited by accredited, competent and independent third-party auditors working with one of the SFM Certification programs.

Canadian provincial governments have developed two basic tenure agreement models: Area-Based and VolumeBased (Fig. 2).

\section{Area-Based Tenures}

The provincial government allocates a specified area of forest to a private sector manager, usually a single forest products company. In some cases several medium-sized companies may rely on one area for their wood supply. The private sector manager (tenure holder) is responsible for preparation of a long-term forest management plan, subject to review and approval by government, as well as all forest operations and post-harvest regeneration. Provided the tenure agreement is secure and extends into the future for a period of 25 years or more, the licensee is able to develop a sense of stewardship for the forest.

\section{Volume-Based Tenures}

The provincial government establishes a forest area under management by the provincial department responsible for forests or by a government agency. This area of forest will usually supply timber to several forest products companies. The public sector manager is responsible for preparation of the long-term forest management plan and allocates areas for annual forest operations to the companies. Post-harvest regeneration may be the responsibility of the public sector manager or the company that carried out the harvest operation. Companies operating under a Volume Agreement are less likely to develop a sense of stewardship. They have no clear stake in the future productivity of the area of forest that they have operated in.

An efficient tenure system should be structured to achieve five objectives essential to ensure good forest management and a competitive industry:

- $\quad$ Secure and dependable long-term tenure agreements.

- Logical and clear allocation of responsibility and accountability for all aspects of forest management and operations. It is important to place the responsibility where it can be carried out in the most efficient way.

- Incentives to increase forest health, growth, productivity and tree quality to support a competitive industry.

- Include forest-dependent communities and First Nations in the long-term planning process to contribute to the long-term prosperity of the forest resource-based communities and to community support for forest management.

- Flexibility in the types of organizations that may hold a tenure agreement- communities, forest products companies, groups of companies or forest management organizations without ownership of a processing facility.

Models of Area and Volume based tenures have not yet developed to the point where they include the participation of forest-dependent communities in management decisionmaking at the forest level. They do not provide any incentive for the tenure-holder to invest in the long-term improvement of forest productivity and timber values, or in non-timber values such as habitat improvement or recreational use. The present tenure system is essentially inflexible.

The authors believe that Area Agreements provide the model that offers the most efficient and effective form of contract to achieve the objectives listed above. But the Area Agreements used over the past 50 years or so can be improved with the inclusion of the five points noted above.

Forest-dependent communities, including First Nations, throughout Canada have had little active participation in forest management decision-making although they are often economically dependent on forest management operations and timber processing. Public participation in the development of long-term forest management plans is important but must recognize the essential responsibilities that reside with the forest managers. Consideration must also be given to the type of forest covered by the specific agreement. An agreement in the Boreal forest, with only 4-5 species used by perhaps three types of wood-using mills, will produce a mix of harvested wood that is much less diverse than an agreement in the Great Lakes-St Lawrence or Acadian forest regions with perhaps 17 commercial species of hardwoods and conifers used by as many as seven types of mills).

We believe that there is some evidence that a different approach is already underway. An early example of what can be accomplished by a provincial government delegating the 
full management of timber on a specific area and its sale to a range of forest industries is illustrated by the success of the Algonquin Forestry Authority (AFA) established by Ontario in 1974. Although responsible directly to the Minister for Natural Resources and Forestry, the Board of Directors of the AFA represent the local communities that are dependent on timber harvested by the Algonquin Forestry Authority. A key result of the AFA silvicultural program, particularly in the maple forests, has been a marked improvement in tree quality, which would not have occurred if the tenure had been left to individual forest company licensees. The forest managed by the AFA is audited and certified to the requirements of the CSA Z-809 SFM Standard.

The model of having a legally established forest management corporation holding the tenure rights rather than one forest company seems to us a pattern that can provide both responsibility and accountability to a Board of Directors that represents local communities, forest products companies and forest interests such as recreation and hunting/fishing. This model may be especially suited to forests with diverse species and round-wood products. In Ontario such forest management corporations already exist with varying representation on their boards of directors. It will be important for the Board to maintain close co-operation with the wood-using industry to ensure that forest productivity and tree quality objectives are set and met.

The combination of communities and companies sharing responsibility for governance and management is important. Communities bring socio-economic interests and community support to the table. Companies bring knowledge of processing and markets as well as insight into emerging trends in the marketplace. Both make important contributions to wellbalanced long-term management decisions. In 2011, provincial legislation broadened this approach with the establishment of a Local Forest Management Corporation (LFMC), the Nawiinginokiima Forest Management Corporation (NFMC), which will be responsible for forest management on the Big Pic Forest covering 1.9 million hectares with an annual allowable cut of 2.2 million cubic metres. The NFMC Board of Directors includes representatives from three First Nations bands, Pic River, Pic Mobert and Hornepayne, and the communities of Marathon, Manitouwadge, Hornepayne and White River.

Abitibi River Forest Management Inc., which manages the Abitibi River Forest is considered to be a notable success. The shareholders include First Nations communities, forest products companies and contractors.

Similar innovations centered on municipalities and First Nations communities are being tried in BC. The recent Supreme Court decision concerning title to lands of the Ts'ilqot'in Nation in BC is another sign that provinces must consider new approaches to the management of public forest lands.

The move to forest management organizations with a community voice holding Area Agreements, providing timber to industry in the surrounding communities, offers an opportunity to combine:

- the right to manage the timber over the long-term;

- a duty to meet timber supply obligations;

- the opportunity and incentive to increase forest productivity and tree quality; and,
- the ability to make decisions on the disposition of timber and other forest values in response to markets.

Forest-dependent communities have a long-term socioeconomic interest in forest productivity as do the forest products companies that depend on the forest for their wood supply. The long-term success of this type of tenure agreement will rely on adequate funding to ensure that forest management and silvicultural treatments are carried out and that investment in forest health, productivity and tree quality are well-planned and executed. Provision for funding must be built into the agreement. The private sector investment in forest productivity and tree quality as well as the development of other forest values in a competitive marketplace will result in economic stimulus to the forest-based communities involved.

In large urbanized provinces such as Quebec, Ontario, Alberta and British Columbia, the direct revenues to the province from timber stumpage payments and area charges are miniscule compared to other revenues. This may result in a province being less concerned about the future prosperity of the forest resource communities and the industry than previously.

There are many competing calls upon the public purse. Some responsibilities may be more compelling than planting trees. When making a choice between public health, education, road repair and public transport in vote-rich urban areas, or tree planting and juvenile spacing on a forest remote from the provincial capital, it is easy to overlook the forest. But if forest management practices are a private sector responsibility, governments will have no difficulty holding them accountable for poor performance. All that is required is political will.

The process of forest management and sale of timber from public forest lands has evolved in response to economic and social conditions, the marketplace and technology. We see the move to community-based management, including secure rights to timber supply for companies, as part of this process. This is particularly relevant in view of the rapid pace of urbanization and consequent lack of knowledge and public concern for the well-being of distant forest-dependent communities. There is reason to be flexible in allocating forest management tenures.

A successful tenure system will provide:

- A secure long-term timber supply to industry

- Incentives to improve forest productivity and tree quality

- Long-term stability in tenure and policy to allow management targets to be set and met

- Availability of funds to ensure fulfillment of management and silvicultural obligations through market cycles

- An influential role for industry in all forest management decisions

- An influential voice for forest-dependent communities that have a long-term interest in the management of the forest

- Private sector management rigour and discipline

- Government oversight to ensure long-term policy goals are met

- Certification to one of the forest management certification programs offers additional assurance of exemplary performance through regular audits by accredited, competent and independent third-party auditors. 
Tenure agreements should be signed under contract law, not under provincial forest management legislation. Forest management should not be subject to political cycles.

\section{Long-term Leasehold}

There is one additional tenure model that is worth mentioning. It has not been used in Canada but it is used in Europe and the USA, mainly on privately owned forest lands. It is a long-term leasehold agreement ${ }^{1}$. New Zealand has used it on public forest lands. The term of a leasehold in Canada should logically match the rotation of $50-80$ years. In Canada the use of such an arrangement would perhaps be considered to be too much like the sale of public forest land to private interestsviewed as a political non-starter. But if the holder of the longterm lease was a partnership between communities, First Nations and one or more forest products companies, the idea might be attractive.

How might it work? The lease-holder would be required to comply with all forest and land management regulations. Annual payments would be based on a calculation of the $\mathrm{AAC}$ of the forest management unit (FMU) and the value of the stumpage due on a harvest of the AAC at the date of signing the agreement. This becomes the annual lease payment. There would be a factor applied to ensure that the annual payment kept pace with inflation and changes in the value of products. The holder of the lease would make this annual payment whether the harvest was at the AAC level or below. The lease holder would benefit from all increases in productivity and timber quality during the period of the lease without triggering an additional increase in the annual payment. This would be the main incentive to make well-judged investments in silvicultural treatments to improve forest health, productivity and tree quality. Statement of forest management objectives: part of the leasehold agreement will be a statement of the condition of the forest and infrastructure (roads, bridges) at the date of signing. A second part of this statement

${ }^{1}$ A leasehold tenure system for publicly owned forest land - Tony Rotherham, The Forestry Chronicle Sept/Oct 2010 Vol 86 \#5 pp 597-600 would be a clear description of the condition of the forest and infrastructure at the end of the lease-perhaps 50-80 years in the future (species, stand size, age-class and spatial distribution). Management operations to meet the end-of-lease target condition will probably have to start in the first year of the lease due to the slow growth of our forests.

\section{Conclusion}

Forest Management as a Joint Venture between Industry and Communities

While there is no doubt the forest product company has a long-term stake in the forest and wood supply, it can be argued that a forest-dependent community has an even longer-term dependency on the health, productivity and quality of the forest than does the company. If this contention is valid there is a strong argument to be made that forestdependent communities should have a role as a joint-tenure or single tenure/management holder and be a participant in the long-term management and governance of the designated forest resource. The voices of the community in support of good forest management and the role of the forest as a supporter of jobs and socio-economic prosperity can be an effective counterbalance to those who argue that forests should be "preserved".

\section{Follow-up}

Forest tenure agreements are of fundamental importance in the management of Canada's publicly owned forests. Perhaps it is time to give some serious thought to developing and implementing a new form of tenure that responds well to modern conditions and the needs of communities and forest products companies.

If readers have ideas they would like to contribute to the discussion please send them to the authors: Tony Rotherham at trotherham@sympatico.ca and Ken Armson at mamkaa@sympatico.ca. Perhaps The Forestry Chronicle will publish a collection of your thoughtful suggestions. The Executive Committee of the CIF/IFC has been invited to attend future meetings of the Canadian Council of Forest Ministers. This offers an excellent opportunity to propose improvements to forest policy-including tenure.

Canadian Institute of Forestry/Institut forestier du Canada
2017 NATIONAL AWARDS
The Canadian Institute of Forestry/
$\begin{aligned} & \text { Nominate a colleague or group in recognition of their outstanding, } \\ & \text { unique accomplishments in forestry in Canada } \\ & \text { c/o The Canadian Ecology Centre } \\ & \text { Canadian Forestry Achievement Award } \\ & \begin{array}{l}\text { Mattawa, Ontario P0H 1V0 } 99,695 \text { Hwy. 17 West } \\ \text { Toll Free: 1-888-747-7577 }\end{array} \\ & \begin{array}{l}\text { Canadian Forestry Scientific Achievement Award } \\ \text { Fax: 705-744-1715 }\end{array} \\ & \begin{array}{l}\text { Canadian Forest Management Group Achievement Award } \\ \text { Email: admin@cif-ifc.org }\end{array} \\ & \text { Presidential Award • Schlich Medal • Honourary Member } \\ & \text { Prince of Wales Award for Sustainable Forestry }\end{aligned}$
List of previous recipients, award criteria and nomination information can be obtained
from the CIF/IFC Web site - www.cif-ifc.org

